\title{
Relationship Between Attitude Towards Mathematics and Mathematical Problem-Solving Achievement Among Pre-University Students in Malaysia
}

\author{
Suriati Abu Bakar ${ }^{1^{*}}$ and Ahmad Fauzi Mohd Ayub ${ }^{1,2}$ \\ ${ }^{1}$ Institute for Mathematical Research, Universiti Putra Malaysia, 43400 UPM Serdang, Selangor, Malaysia. \\ ${ }^{2}$ Faculty of Educational Studies, Universiti Putra Malaysia, 43400 UPM Serdang, Selangor, Malaysia.
}

\begin{abstract}
The purpose of this study was to identify the relationship between attitude towards mathematics and problem-solving achievement among pre-university students. The sample of the study consisted of 312 One-year Matriculation Programme students from three matriculation colleges. The Attitude Toward Mathematics Inventory (ATMI) and a mathematical test were used in data collection. The results indicated that students had a high level of attitude towards mathematics. Inferential analysis showed a significant positive relationship between overall attitude towards mathematics with mathematical problem-solving achievement. Four sub-factors, i.e., self-confidence, value, enjoyment and motivation were found to have positive significant relationship with problem solving achievement. As a result, from these findings, recommendations were identified for future research.
\end{abstract}

Keywords: attitude; self-confidence; enjoyment; problem solving; m achievement

\section{INTRODUCTION}

Students' attitude towards mathematics and achievement has been widely discussed in relation to mathematics education research (Mensah, Okyere, \& Kuranchie, 2013). Beside cognitive factors, students' attitude also has been accepted as a key factor that influence students achievement (Mensah et al., 2013;Abu \& Leong, 2014). According to Ayob and M. Yasin (2017), positive perceptions of mathematics learning among students will develop positive attitudes towards mathematics and lead to higher achievement.

Zan and Di Martino (2007) defined mathematics attitude as a positive or negative attitude on emotional disposition towards mathematics, while Hart (1989) referred mathematics attitude as individual's emotion response towards mathematics, beliefs in mathematics and how they behaves towards mathematics. Hannula (2002) defined attitude based on three components, namely, emotional, beliefs and behaviour. Di Martino and Zan (2010) suggested that cognitive must also be integrated as part of mathematics attitude component. Therefore, the definition of mathematics attitude has been expanded based on three components, namely, affective (i.e. emotional and beliefs), behaviour and cognitive (Ayob \& M. Yasin, 2017). Positive attitude towards mathematics affect students willingness to learn mathematics compared with students with negative mathematics attitude, and once they feel that mathematics is important, they will try to improve their mathematics achievement (Ajisuksmo \& Saputri, 2017). In the context of this study, students' attitude toward mathematics was evaluated from four aspects, namely, self-confidence, value, enjoyment, and motivation.

Previous studies have shown that attitude could affect students' learning and achievement. For instance, Burrus and Moore (2016) found that there was a significant relationship between attitudes towards mathematics and mathematics achievement among high school students.Meanwhile, Mohd and Mahmood (2011) exhibited that attitude towards mathematics had a significant influence on university students' mathematics achievement.Other studies have also demonstrated that attitude towards mathematics was significantly related to

\footnotetext{
*Corresponding author's e-mail: suriedd@gmail.com
} 
mathematics achievement (Bakar et al., 2010;Guven \& Cabakcor, 2013; Lim \& Chapman, 2015). In a university calculus course, Pyzdrowski et al. (2013) found that selfconfidence, which was mathematics attitude component, had the strongest relationship with students' achievement. Students who were interviewed by them also said that a lack of confidence can caused difficulties and positive attitudes will contribute to success.Quaye (2015) study among secondary schools students demonstrated positive significant relationship between attitude towards mathematics and achievement. Considering all of the findings and support from previous studies, it seems students' attitude towards mathematics was importance in mathematics teaching and learning.

\section{Objective of The Study}

The objective of this study was to investigate the relationship of attitudes towards mathematics (self-confidence, value, enjoyment and motivation) on mathematical problem solving achievement among pre-university students.

\section{METHODOLOGY}

This quantitative correlational study employed a cluster sampling procedure. A total of 312 students from the matriculation programme under the Ministry of Education Malaysia were randomly selected. A list of colleges was divided into three zones namely North, Central and South zones and for each zone the number of matriculation students were proportionately calculated. By using fishbowl technique, three colleges were selected randomly in each zone for the actual data collection process. The selected colleges were Kolej Matrikulasi Perak (North zone), Kolej Matrikulasi Negeri Sembilan (Central zone) and Kolej Matrikulasi Melaka (South zone). Respondents were selected randomly from the three selected colleges based on the list provided by respective college directors.

A survey questionnaire was used for the data collection. Data were collected using 40 items adapted from the Attitude Toward Mathematics Inventory (ATMI) by Tapia and Marsh (2004)to evaluate students' attitude towards mathematics. A mathematics test was conducted to determine the students' mathematical problem-solving achievement. This instrument for the students' attitude towards mathematics consisted of four factors, i.e., (a) self- confidence (15 items); (b) value (10 items); (c) enjoyment (10 items) and (d) motivation (5 items).

According to (Tapia \& Marsh, 2004), self-confidence measure students' confidence and self-concept of their mathematics achievement. Value look into students' beliefs on the functionality, pertinent and worth of mathematics in their life now or later. Meanwhile, enjoyment indicates the degree to which students enjoy solving mathematics problems and mathematics classrooms. Finally, motivation measures students' interest in mathematics and desire to further studies in mathematics beyond the college level. Respondents were given options using a five-point Likert scale ranging from 1 (strongly agree) to 5 (strongly disagree) to measure their agreement on the questionnaire items. Whereas mathematical problem-solving achievement was determined on the total score marks on mathematics test.

The data were analysed using the IBM SPSS Statistics Version 22 software. The reliability analysis was done on the questionnaire items using Cronbach's alpha value to students' who were not involved in the actual study. Table 1 shows the results of the Cronbach's alpha values obtained from the pilot study. The Cronbach's alpha value for each dimension ranged from 0.823 to 0.939 , which indicated that the questionnaire items used to measure students' attitude towards mathematics were reliable(Cohen, Manion, \& Morrison, 2007).

Table 1. Cronbach Alpha Values

\begin{tabular}{lc}
\hline Variables & $\begin{array}{c}\text { Cronbach's } \\
\text { alpha value }\end{array}$ \\
\hline Self-confidence & 0.939 \\
Value & 0.823 \\
Enjoyment & 0.885 \\
Motivation & 0.834 \\
Overall students' attitude towards & 0.959 \\
mathematics & \\
\hline
\end{tabular}

\section{RESULTS AND DISCUSSIONS}

A total of 312 respondents were randomly selected in this study, which consisted of 106 males (34.0\%) and 206 (66.0\%) females. The results of the descriptive statistics that indicated students' attitude towards mathematics were based on mean scores ranging from 3.50 to 4.27 (Table 2). The overall mean students' attitude towards mathematics was $3.91(\mathrm{SD}=0.57)$, which indicated students held a high 
level of attitude towards mathematics.

The highest mean score revealed from the descriptive analysis was on value $(\mathrm{Mean}=4.27, \mathrm{SD}=0.64)$. This finding indicated the students perceived highly that learning mathematics was beneficial in their lives. They agreed they had a desire to develop their mathematical skills because mathematics could help them develop their mind to think differently on the applications of mathematics in their daily life.

The second highest mean was enjoyment (Mean=4.03, $\mathrm{SD}=0.62$ ). This showed students had a high tendency to enjoy learning mathematics in mathematics classroom. It could be summarised that students got satisfaction when solving mathematics problems and they felt happier solving mathematics problems compared to other subjects.

The third highest mean was on self-confidence (Mean=3.71, SD=0.73), which indicated most of the students had a high tendency to believe they had self-confidence and positive self-concept about their mathematics achievement. They agreed they found it interesting when they heard the word mathematics and felt relaxed when thinking about having to solve mathematics problems.

Motivation had the lowest mean in students' attitude towards mathematics (Mean=3.50, $\mathrm{SD}=0.83$ ). This showed students had a high tendency to continue studying mathematics at the tertiary level. In summary, it appeared the students had the intention to continue doing mathematics at universities.

Table 2. Mean and Standard Deviation for Students' Attitude towards Mathematics

\begin{tabular}{lcc}
\hline Variables & Mean & SD \\
\hline Self-confidence & 3.71 & 0.73 \\
Value & 4.27 & 0.46 \\
Enjoyment & 4.03 & 0.62 \\
Motivation & 3.50 & 0.83 \\
\hline Overall Mean and & 3.91 & 0.57 \\
Standard Deviation & & \\
\hline
\end{tabular}

The correlation between students' attitude towards mathematics and mathematical problem-solving achievement was tested using the Pearson's product moment correlation analysis to determine whether there was any significant relationship between the variables. The normality for the data was examined before using Pearson correlation test. The value for skewness and kurtosis in Table 3 shows the value for normality for each of the variables. The value of skewness and kurtosis should be within the range of \pm 2 to indicate it is normally distributed(Garson, 2012).

Table 3. Normality Assumption based on Skewness and

\begin{tabular}{lcc}
\multicolumn{3}{c}{ Kurtosis } \\
\hline Variables & Skewness & Kurtosis \\
\hline Self-confidence & -0.317 & -0.323 \\
Value & -0.432 & -0.542 \\
Enjoyment & -0.348 & -0.539 \\
Motivation & -0.093 & -0.460 \\
Achievement & 0.561 & -0.876 \\
\hline
\end{tabular}

The data analysis showed that there was a significant positive relationship between the overall attitude towards mathematics with mathematical problem-solving achievement $\left(\mathrm{r}=0.489^{* *}, \mathrm{p}<0.001\right)$. According to Lodico, Spaulding and Voegtle (2006), this was moderate strong relationship. Meanwhile, there were significant positive relationship between self-confidence $\left(\mathrm{r}=0.524^{* *}, \mathrm{p}<\right.$ o.001), value $\left(\mathrm{r}=0.271^{* *}, \mathrm{p}<0.001\right)$, enjoyment $\left(\mathrm{r}=0.431^{* *}\right.$, $\mathrm{p}<0.001)$ and motivation( $\left.\mathrm{r}=0.374^{* *}, \mathrm{p}<0.001\right)$ on mathematical problem solving achievement (see Table 4).It could be concluded the students with high attitude towards mathematics tended to obtain high mathematical problem solving achievement.

Table 4. Relationship between Students' Attitude towards Mathematics and Mathematical Problem-Solving Achievement

\begin{tabular}{ccccc}
\hline & $\begin{array}{c}\text { Self- } \\
\text { confidence }\end{array}$ & Value & Enjoyment Motivation \\
\hline Achievement & $0.524^{* *}$ & $0.271^{* *}$ & $0.431^{* *}$ & $0.374^{* *}$ \\
& 0.000 & 0.000 & 0.000 & 0.000 \\
\hline
\end{tabular}

${ }^{* *}$ Correlation is significant at the 0.01 level

\section{SUMMARY}

Students' attitude in mathematics learning had been widely studied by previous researches. In fact, studies had shown students' attitude in solving mathematical problems are essential to ensure outstanding academic achievement (Zakaria \& Yusoff, 2009).This study aims to see the relationship of attitude towards mathematics on mathematical problem solving achievement of preuniversity students. Analysis of the overall mean revealed students' attitude towards mathematics was at the high level. 
There was a moderate strong correlation between the overall mean attitude towards mathematics and its dimensions with mathematical problem-solving achievement.

It was discovered that students concurred that mathematics was one of the most important subjects to learn and it was worth to study advanced mathematics as it was beneficial to them. They agreed they really liked mathematics because mathematics was a very interesting subject and they usually enjoyed studying mathematics in college. In addition, students had a lot of self-confidence when solving mathematics problems and they expected to do fairly well in any mathematics class they undertook. They were confident they could continue learn advanced mathematics at university level.

Previous study had showed the existence of relationship of pre-university education on the engineering students' performance at university level (Kamal et al., 2015).Therefore, efforts should be made by all lecturers to augment students' attitudes towards mathematics as these would push them to achieve higher in the learning process. More student-oriented class activities should be conducted to develop students' interest in Science, Technology, Engineering and Mathematics (STEM). By preparing conducive learning experience can developed more positive attitudes towards mathematics. 


\section{REFERENCES}

Abu, N. E., \& Leong, K. E. (2014). Hubungan antara sikap, minat, pengajaran guru dan pengaruh rakan sebaya terhadap pencapaian Matematik tingkatan 4. Jurnal Kurikulum \& Pengajaran Asia Pasifik, 2(1), 1-10. https://doi.org/10.11113/jt.v39.477

Ajisuksmo, C. R. P., \& Saputri, G. R. (2017). The influence of attitudes towards mathematics, and metacognitive awareness on mathematics achievements. Creative Education, 8(3), 486-497.

Ayob, A., \& M. Yasin, R. (2017). Factors affecting attitudes towards mathematics. International Journal of Academic Research in Business and Social Sciences, 7(11), 1100-1109.

Bakar, K. A., Tarmizi, R. A., Mahyuddin, R., Elias, H., Luan, W. S., \& Ayub, A. F. M. (2010). Relationships between university students' achievement motivation, attitude and academic performance in Malaysia. Procedia - Social and Behavioral Sciences, 2(2), 4906-4910.

Burrus, J., \& Moore, R. (2016). The incremental validity of beliefs and attitudes for predicting mathematics achievement. Learning and Individual Differences, 50, 246251.

Cohen, L., Manion, L., \& Morrison, K. (2007). Research Quaye, J. (2015). Exploring students' attitudes towards methods in education (6th ed.). New York: Routledge.

Di Martino, P., \& Zan, R. (2010). "Me and maths": Towards a definition of attitude grounded on students' narratives. Journal of Mathematics Teacher Education, 13(1), 27-48.

Garson, G. D. (2012). Testing statistical assumptions. Tapia, M., \& Marsh, G. E. I. (2004). An Instrument to Asheboro, NC: Statistical Associates Publishing.

Guven, B., \& Cabakcor, B. O. (2013). Factors influencing mathematical problem-solving achievement of seventh Zakaria, E., \& Yusoff, N. (2009). Attitudes and problemgrade Turkish students. Learning and Individual Differences, 23(1), 131-137.

Hannula, M. S. (2002). Attitude towards mathematics: Emotions, expectations and values. Educational Studies in Z Mathematics, 49(1), 25-46.

Hart, L. E. (1989). Describing the affective domain: saying what we mean. In D. B. McLeod \& V. M. Adams (Eds.), Affect and Mathematical Problem Solving (pp. 37-45). New York, USA: Springer Verlag.

Kamal, N., Arsad, N., Husain, H., \& Nopiah, Z. M. (2015). The relationships between pre-university education and mathematics achievement with performance in engineering subject. Journal of Engineering Science and Technology, (Special Issue on UKM Teaching and
Learning Congress 2013), 10-17.

Lim, S. Y., \& Chapman, E. (2013). Identifying affective domains that correlate and predict mathematics performance in high-performing students in Singapore. Educational Psychology, 35(6), 747-764.

Lodico, M. G., Spaulding, D. T., \& Voegtle, K. H. (2006). Methods in educational research: From theory to practice. San Francisco: Jossey-Bass.

Mensah, J. K., Okyere, M., \& Kuranchie, A. (2013). Student attitude towards Mathematics and performance: Does the teacher attitude matter? Journal of Education and Practice, 4(3), 132-139.

Mohd, N., \& Mahmood, T. F. P. T. (2011). The effects of attitude towards problem solving in mathematics achievements. Australian Journal of Basic and Applied Sciences, 5(12), 1857-1862.

Pyzdrowski, L. J., Sun, Y., Curtis, R., Miller, D., Winn, G., \& Hensel, R. A. M. (2013). Readiness and attitudes as indicators for success in college calculus. International Journal of Science and Mathematics Education, 11(3), 529-554.

mathematics and mathematical achievement in secondary schools in England: the role of social class, gender and ethnicity. Research in Mathematics Education, 17(1), 59-60.

Measure Mathematics Attitudes. Academic Exchange Quarterly, 8(2), 16-21.

Solving skills in algebra among Malaysian matriculation college students. European Journal of Social Sciences, 8(2), 232-245.

Zan, R., \& Di Martino, P. (2007). Attitude toward mathematics: Overcoming the positive/negative dichotomy. The Montana Mathematics Enthusiast, 3, 157-168. 